\title{
UJI AKTIVITAS ANTIOKSIDAN HASIL DEGRADASI LIGNIN DARI SERBUK GERGAJI KAYU KALBA (Albizia falcataria) DENGAN METODE TBA (Thio Barbituric Acid)
}

\author{
Undri Rastuti dan Purwati
}

Program Studi Kimia, Jurusan MIPA, Fakultas Sains dan Teknik UNSOED

\begin{abstract}
Antioxidants are compounds that can delay, retard or inhibit the oxidation reaction. Lignin is a natural polymer consisting of monomeric substituted phenols. Wood lignin degradation Kalba (Albizia falcataria) yields substituted phenol. The purpose of this study was to test the antioxidant activity of compounds of lignin degradation products Kalba using TBA (Thiobarbituric Acid). Wood lignin degradation products Kalba tested antioxidant activity using the TBA method. Phase test phase of this antioxidant activity is sample preparation, determination of the maximum wavelength, determination of equilibrium time, absorbance measurements and determination of the percentage of inhibition. The wavelength maximum for BHT test solution was obtained at $530 \mathrm{~nm}$. The stability of absorbance achieved after 80 minutes equilibrium time. BHT test solution and sample solution containing the degradation of lignin $0.10 \%(\mathrm{w} / \mathrm{v})$ increased but not as sharp as the absorbance of control, this suggests that the degradation of wood lignin Kalba have activity as an antioxidant, which relative minimize 13,70 \% compare with BHT.
\end{abstract}

Keyword: Lignin, Albizia falcataria, degradation, antioxidant.

\section{PENDAHULUAN}

Kemajuan industri berbahan baku pohon kalba (Albizia falcataria) menimbulkan berbagai permasalahan, salah satunya adalah adanya sisa serbuk gergaji pohon kalba yang terbuang begitu saja. Umumnya, sisa serbuk gergaji hanya digunakan sebagai bahan bakar pengganti kayu. Pemanfaatan limbah serbuk gergaji pohon kalba sangat diharapkan, karena dalam limbah ini masih terdapat komponen-komponen kimia yang penting seperti selulosa dan lignin.

Lignin merupakan salah satu komponen penyusun tanaman. Secara umum, tanaman terbentuk dari selulosa, hemiselulosa, dan lignin. Komposisi bahan penyusun ini berbeda-beda bergantung pada jenis tanaman. Lignin adalah polimer alam yang terdiri dari monomer fenol tersubstitusi. Lignin terbentuk dari gugus aromatik yang saling dihubungkan dengan rantai alifatik, yang terdiri dari 2 sampai 3 atom karbon .
Gambar struktur lignin dapat dilihat pada Gambar 1.

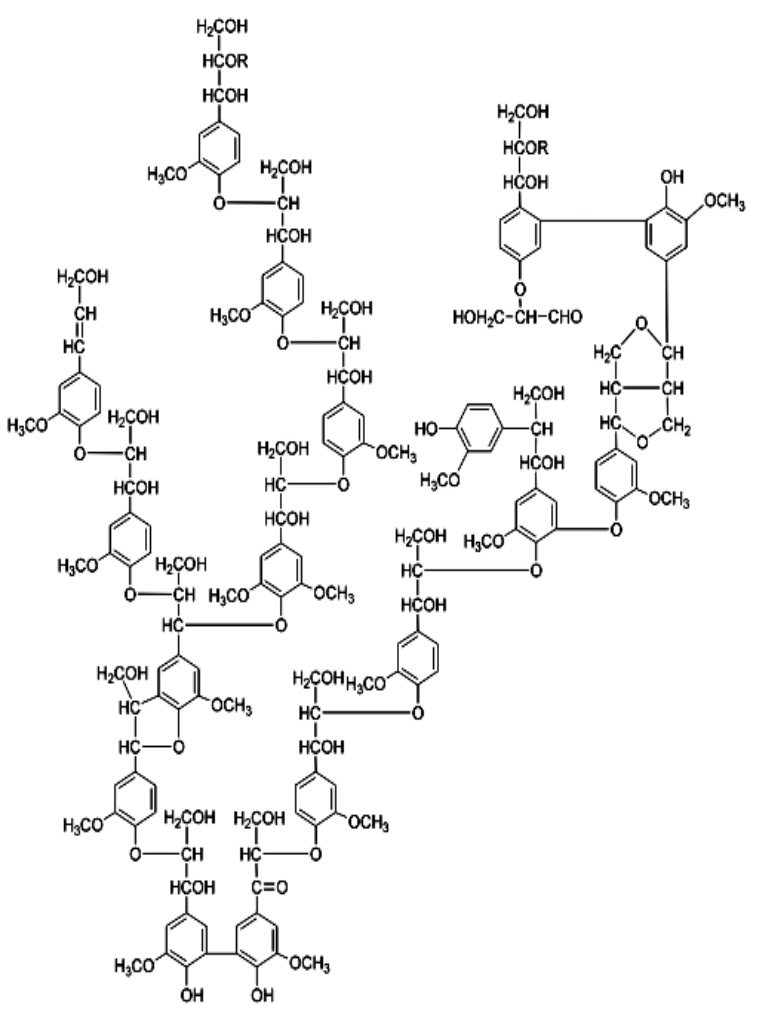

Gambar 1. Struktur lignin 
Pada proses pirolisa lignin, dihasilkan senyawa kimia aromatis yang berupa fenol, terutama kresol. Lignin dapat diisolasi dari jaringan tumbuhan dengan berbagai metode, salah satunya adalah metode Klason, yang menggunakan asam sulfat $60 \%$. Metode ini banyak digunakan karena sederhana dan lignin yang diperoleh dapat mencapai jumlah yang relatif besar. Rastuti dan Purwati (2010) telah melakukan isolasi dan degradasi lignin menghasilkan senyawa fenolik, yaitu: 2-metoksi fenol (Guaiacol); 1,2 Benzenediol (Pyrocatechol); 3-metoksi 1,2 Benzenediol dan 2-metoksi 4-(1E) propenil fenol (isoeugenol). Senyawasenyawa fenolik ini dapat bermanfaat sebagai antioksidan.

Antioksidan merupakan senyawa yang dapat menghambat spesies oksigen reaktif/spesies nitrogen reaktif dan juga radikal bebas sehingga antioksidan dapat mencegah penyakit-penyakit yang berhubungan dengan radikal bebas seperti kanker, kardiovaskuler dan penuaan (Halliwell dan Gutteridge, 2000). Antioksidan juga didefinisikan sebagai senyawa yang mampu menunda, memperlambat atau menghambat reaksi oksidasi pada makanan yang dapat mengakibatkan ketengikan (rancidity) pada makanan maupun kerusakan (degradasi) pada obat (Pokorny et al., 2001).

Antioksidan banyak digunakan untuk menghambat proses oksidasi terhadap produk, sehingga produk lebih awet (Trilaksani, 2002). Penggunaan antioksidan alami merupakan alternatif terbaik untuk mengatasi efek samping yang ditimbulkan antioksidan sintetik. Antioksidan alami memiliki efek antikarsinogenik yang dapat menghambat reaksi oksidasi biologis yang berbahaya bagi tubuh (Widjaya, 2003). Mengingat kandungan lignin kayu kalba cukup tinggi, maka perlu dilakukan penelitian untuk mengetahui aktivitas hasil degradasi lignin pada kayu kalba sebagai antioksidan alami.

\section{METODE PENELITIAN}

\section{Bahan dan Alat}

Sampel (Hasil degradasi lignin), asam linoleat $1 \%(\mathrm{v} / \mathrm{v})$, TCA $20 \%(\mathrm{~b} / \mathrm{v})$, TBA $0,67 \%(\mathrm{~b} / \mathrm{v})$, BHT $0,05 \%(\mathrm{~b} / \mathrm{v})$, buffer fosfat $\mathrm{pH} \mathrm{7,} \mathrm{aquades,} \mathrm{spektrofotometer}$ UV-Vis, oven, termometer, dan alat-alat gelas.

\section{Preparasi Sampel}

Larutan uji dibuat dengan cara menambahkan $16 \mathrm{~mL}$ buffer fosfat $\mathrm{pH}$ 7,0 dan $20 \mathrm{~mL}$ asam linoleat $1 \%(\mathrm{v} / \mathrm{v}) \mathrm{ke}$ dalam $4 \mathrm{~mL}$ sampel $0,05 \%$ (b/v) dan $0,07(\mathrm{~b} / \mathrm{v})$. Kontrol adalah asam linoleat dengan perlakuan sama tanpa zat yang bersifat antioksidan, sedangkan pembanding pada sampel digunakan BHT $0,05 \%$ (b/v). Larutan ini disimpan dalam oven yang suhunya diatur tetap 60 ${ }^{0} \mathrm{C}$.

\section{Penentuan Panjang Gelombang Maksimum}

Sebanyak $2 \mathrm{~mL}$ larutan uji standar BHT 0,05\% ditambah $1 \mathrm{~mL}$ TBA 0,67\% (b/v) dan $2 \mathrm{~mL}$ TCA $20 \%(\mathrm{~b} / \mathrm{v})$ diinkubasi dalam oven dengan suhu $60^{\circ} \mathrm{C}$ selama 24 jam. Campuran kemudian didinginkan selama 1 jam. Larutan tersebut diukur absorbansinya pada panjang gelombang 450-600 nm dengan selang $10 \mathrm{~nm}$. Panjang gelombang yang menunjukkan absorbansi tertinggi merupakan panjang gelombang maksimum.

\section{Penentuan Waktu Setimbang}

Sebanyak $2 \mathrm{~mL}$ larutan uji standar BHT 0,05\% ditambah $1 \mathrm{~mL}$ TBA $0,67 \%$ (b/v) dan $2 \mathrm{~mL}$ TCA $20 \%(\mathrm{~b} / \mathrm{v})$ diinkubasi dalam oven dengan suhu $60^{\circ} \mathrm{C}$ selama 24 jam. Larutan kemudian diukur absorbansinya pada panjang gelombang maksimum. Pengukuran dimulai dari 10 
menit sampai 100 menit selama pemanasan dengan selang waktu 10 menit setiap pengukuran. Waktu setimbang ditentukan melalui data antara absorbansi larutan standar terhadap variasi waktu yang menghasilkan waktu setimbang.

\section{Pengukuran Absorbansi}

Pengamatan dilakukan terhadap campuran $2 \mathrm{~mL}$ larutan uji BHT 0,05\% ditambah $1 \mathrm{~mL}$ TBA $0,67 \%(\mathrm{~b} / \mathrm{v})$ dan 2 $\mathrm{mL}$ TCA $20 \%(\mathrm{~b} / \mathrm{v})$ diinkubasi dalam oven dengan suhu $60^{\circ} \mathrm{C}$ selama 24 jam. Dinginkan selama waktu setimbang. Pengamatan dilakukan setiap 24 jam selama 7 hari dengan mengukur absorbansi masing-masing larutan tersebut pada panjang gelombang maksimum.

\section{Penentuan Persentase Penghambatan}

Persentase penghambatan dapat dihitung dengan menggunakan persamaan sebagai berikut:

Persen Penghambatan $=\frac{\left(A_{1}-A_{2}\right)}{A_{1}} \times 100 \%$ dengan,

$\mathrm{A}_{1}=$ Absorbansi kontrol

$\mathrm{A}_{2}=$ Absorbansi sampel
HASIL DAN PEMBAHASAN

Uji aktivitas antioksidan dilakukan dengan beberapa tahapan, masing-masing tahapan dapat diterangkan sebagai berikut:

\section{Pembuatan larutan uji}

Larutan uji disimpan dalam oven yang suhunya $60^{\circ} \mathrm{C}$ selama 24 jam. Tujuan penyimpanan larutan uji dalam oven untuk mempercepat proses oksidasi pada asam lemak, yiatu asam linoleat.

\section{Penentuan panjang gelombang maksimum \\ Penentuan panjang gelombang} maksimum diperlukan untuk menetapkan serapan zat maksimum terhadap sinar pada panjang gelombang tertentu. Panjang gelombang maksimum ditentukan oleh absorbansi tertinggi dari beberapa absorbansi larutan yang diukur. Penelitian ini dilakukan pada panjang gelombang 450-600 nm. Grafik hasil pengukuran absorbansi untuk mengetahui panjang gelombang maksimum disajikan pada Gambar 2. Berdasarkan grafik terlihat bahwa panjang gelombang maksimum untuk larutan uji BHT diperoleh pada $530 \mathrm{~nm}$.

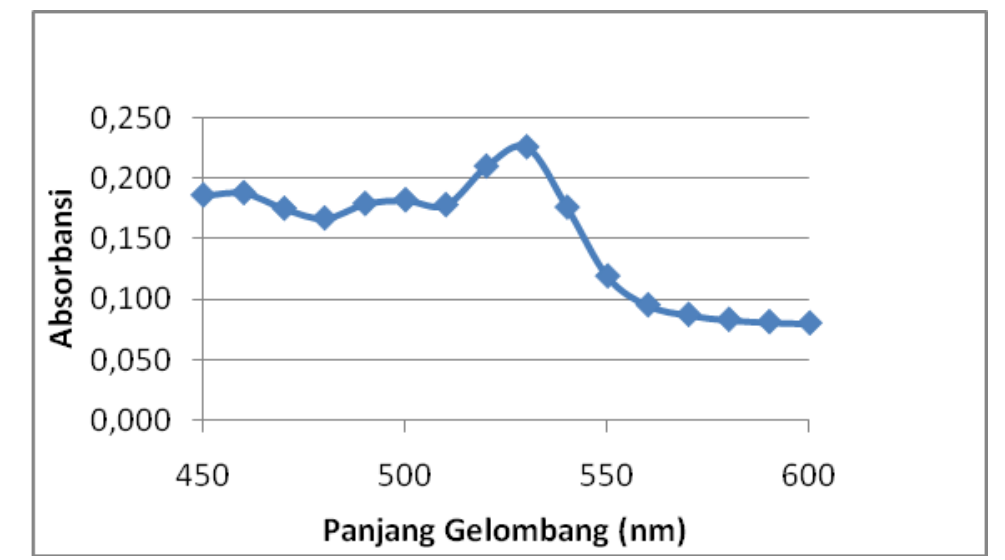

Gambar 2. Grafik penentuan panjang gelombang maksimum

\section{Penentuan waktu setimbang}

Waktu setimbang reaksi ditentukan pada panjang gelombang maksimum yakni $530 \mathrm{~nm}$. Waktu setimbang dicapai dengan melihat kestabilan absorbansi pada rentang waktu tertentu. Grafik pengamatan waktu setimbang disajikan pada Gambar 3. 


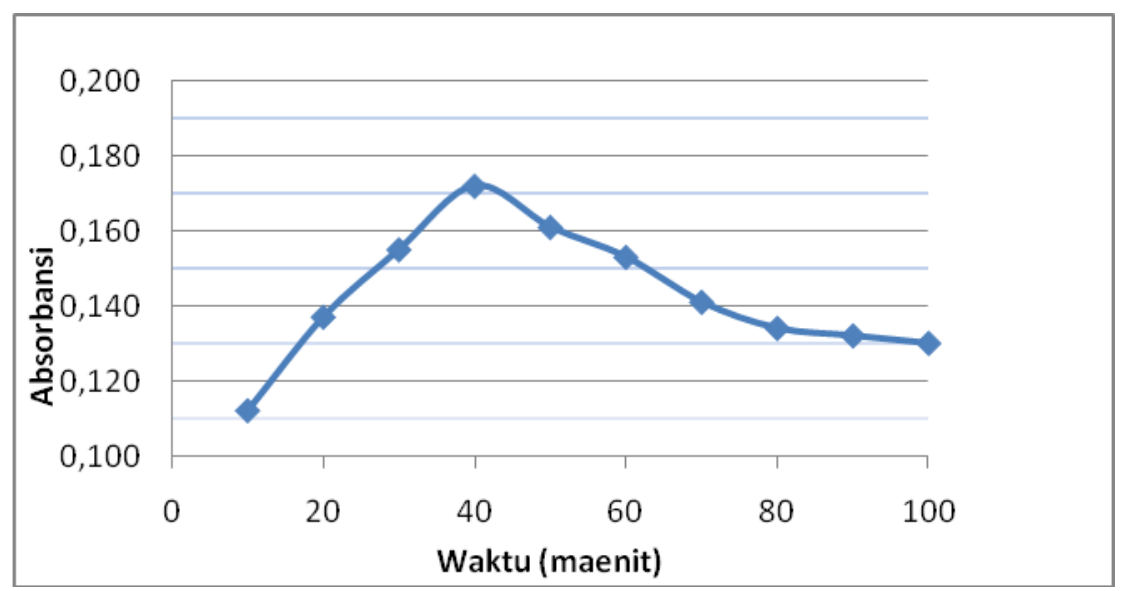

Gambar 3. Grafik penentuan waktu setimbang

Grafik penentuan waktu setimbang digunakan untuk melihat kestabilan absorbansi yang ditunjukkan dengan garis mendatar pada grafik. Waktu setimbang mengindikasikan bahwa reaksi antara pereaksi TBA dengan produk sekunder oksidasi asam linoleat telah mencapai kesetimbangan. Berdasarkan Gambar 2. kestabilan absorbansi dicapai setelah waktu 80 menit.

\section{Pengukuran aktivitas antioksidan}

Pengukuran absorbansi dilakukan pada larutan uji yakni $4 \mathrm{~mL}$ larutan uji BHT 0,05\% (b/v), hasil degradasi lignin $0,10 \%(\mathrm{~b} / \mathrm{v})$ dan kontrol yang masingmasing ditambahkan dengan $2 \mathrm{~mL}$ TBA $0,67 \%$ (b/v) dan $4 \mathrm{~mL}$ TCA $20 \%$ (b/v) kemudian dioven pada suhu $60^{\circ} \mathrm{C}$.
Pengukuran aktivitas antioksidan hasil degradasi lignin dilakukan dengan metode TBA yakni mengukur absorbansi senyawa senyawa kompleks yang terbentuk dari reaksi antara TBA dengan hasil oksidasi sekunder asam linoleat pada panjang gelombang $530 \mathrm{~nm}$. Pengukuran dilakukan setelah larutan uji dibiarkan selama aktu setimbang yaitu 80 menit. Pengamatan dan pengukuran dilakukan selama 4 hari. Hasil pengamatan menunjukkan bahwa nilai absorbansi cenderung meningkat dari hari ke-1 hingga hari ke-4 karena semakin lama waktu penyimpanan menaikkan proses oksidasi. Data pengamatan/pengukuran aktivitas antioksidan dapat dilihat pada Gambar 4.

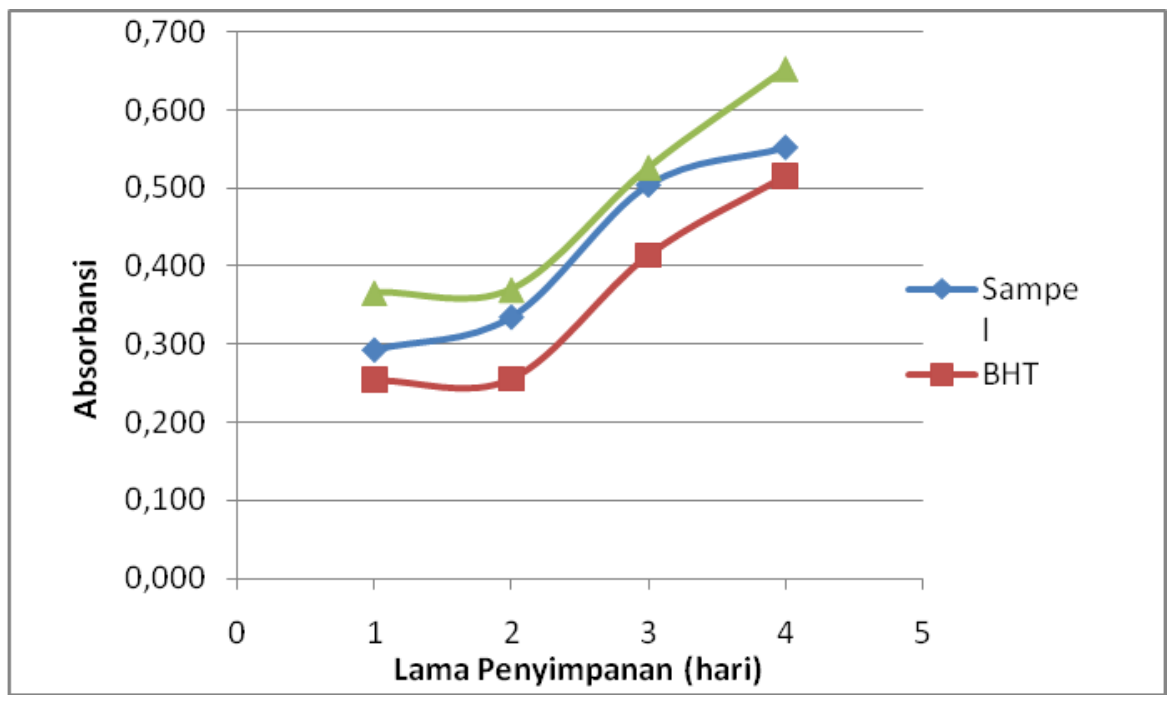

Gambar 4. Grafik pengukuran aktivitas antioksidan 
Larutan uji BHT dan larutan sampel yang mengandung hasil degradasi lignin $0,10 \% \quad(\mathrm{~b} / \mathrm{v}) \quad$ mengalami kenaikan absorbansi tetapi tidak setajam kontrol, ini disebabkan adanya penambahan senyawa yang bersifat antioksidan. Senyawa antioksidan ditambahkan ke dalam suatu bahan untuk menghambat reaksi oksidasi dengan udara. Reaksi tahapan proses oksidasi asam linoleat dapat dilihat pada Gambar 5, 6 dan 7 . Pada tahap inisiasi (Gambar 5.), atom hidrogen lepas dari atom karbon yang bersebelahan dengan ikatan rangkap dua dapat terjadi karena panas, cahaya dan logam (Deman, 1997).

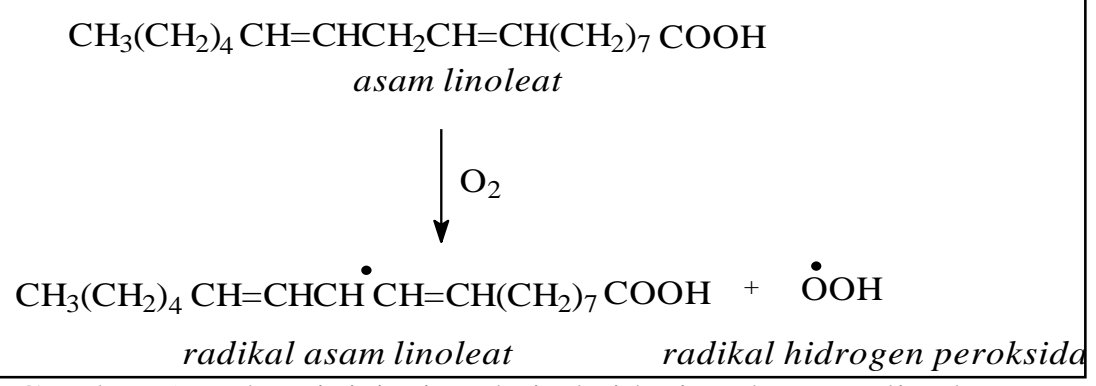

Gambar 5. Tahap inisiasi reaksi oksidasi pada asam linoleat

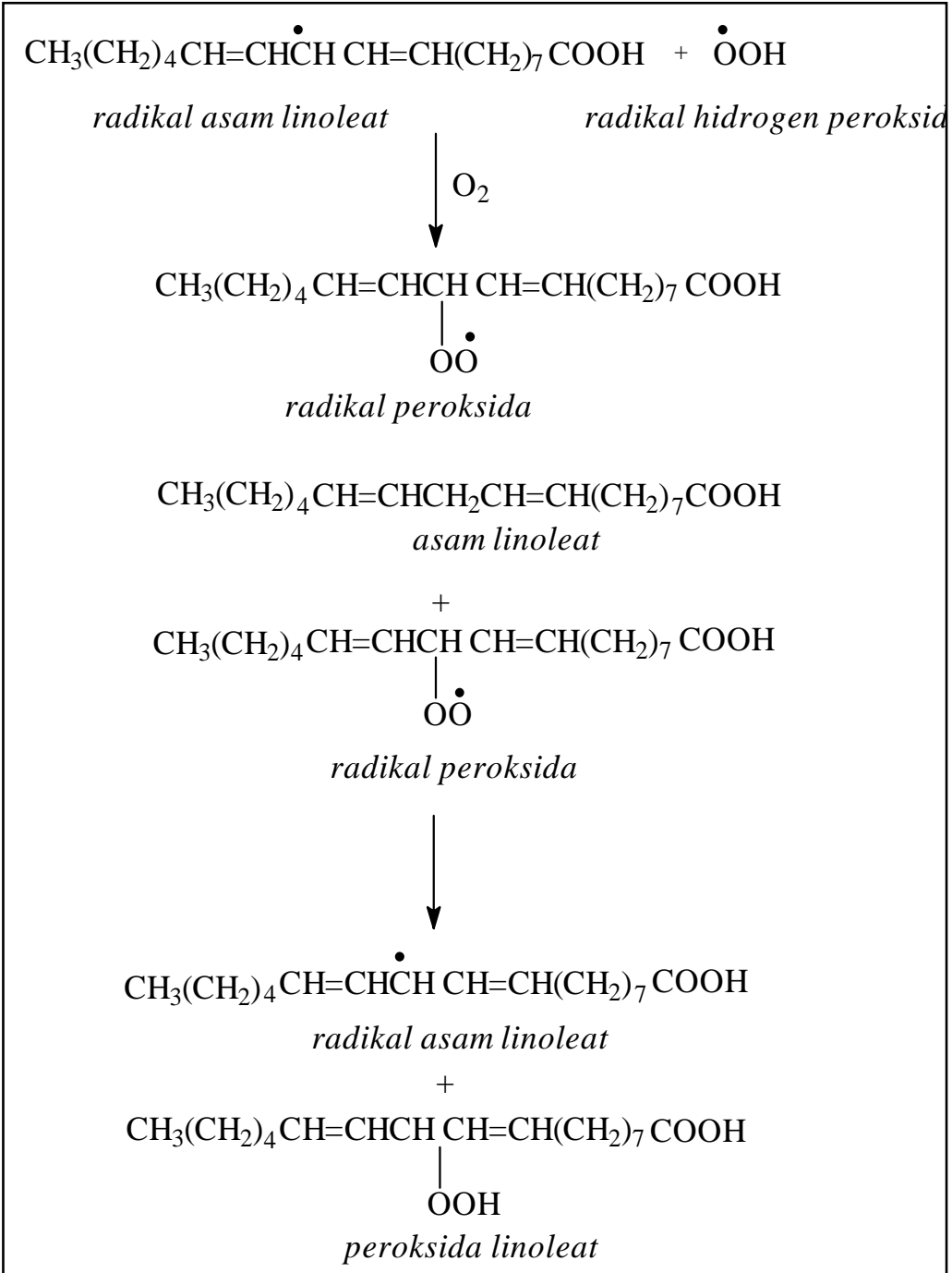

Gambar 6. Tahap propagasi reaksi oksidasi pada asam linoleat 
Molekul, Vol. 5. No. 2. Nov, 2010 : 98 - 104

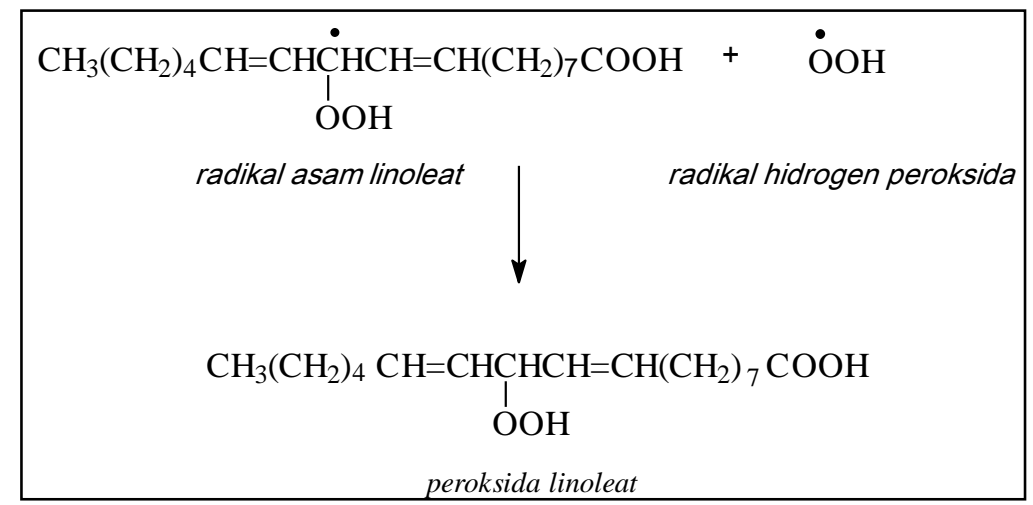

Gambar 7. Tahap terminasi reaksi oksidasi pada asam linoleat

Antioksidan hanya berfungsi menghambat reaksi oksidasi dan tidak dapat menghentikan sama sekali proses autooksidasi pada lemak sehingga pada akhir proses ketengikkan akan terjadi. Hal ini sesuai dengan pendapat Trilaksani (2002) bahwa penambahan senyawa antioksidan pada minyak akan menyebabkan terhambatnya pembentukkan produk sekunder terutama malonaldehid. Malonaldehid ini diidentifikasi dengan TBA menghasilkan warna merah muda. Semakin pekat warna yang dihasilkan menunjukkan semakin meningkat proses oksidasi pada asam linoleat.

\section{Perhitungan persentase penghambatan oksidasi (Faeda, 2001)}

Absorbansi yang diperoleh dari masing-masing larutan uji, kemudian dihitung persentase penghambatannya yakni dengan menghitung pembagian antara selisih nilai absorbansi sampel dan kontrol. Besarnya nilai penghambatan proses oksidasi dari masing-masing larutan uji dan kontrol sebagai hasil nominal dari nilai persentase penghambatan dapat dilihat pada Tabel 4.1. Berdasarkan Tabel 4.1 persentase penghambatan rata-rata hasil degradasi lignin $13,70 \%$ lebih rendah dibanding BHT.

Tabel 4.1. Persentase penghambatan oksidasi asam linoleat oleh BHT dan hasil degradasi lignin terhadap kontrol dengan metode TBA

\begin{tabular}{|c|c|c|c|c|c|}
\hline \multirow{2}{*}{$\begin{array}{c}\text { Inkubasi } \\
\text { (hari) }\end{array}$} & \multicolumn{3}{|c|}{ Absorbansi } & \multicolumn{2}{c|}{ Persen Penghambatan (\%) } \\
\cline { 2 - 6 } & Sampel(A) & BHT (B) & kontrol (C) & A & B \\
\hline 1 & 0,293 & 0,254 & 0,366 & 19,95 & 30,60 \\
\hline 2 & 0,335 & 0,256 & 0,370 & 9,46 & 30,81 \\
\hline 3 & 0,504 & 0,414 & 0,526 & 4,18 & 21,29 \\
\hline 4 & 0,552 & 0,515 & 0,652 & 15,34 & 21,01 \\
\hline
\end{tabular}

\section{KESIMPULAN}

Berdasarkan hasil penelitian ini, maka dapat disimpulkan bahwa senyawa hasil degradasi lignin serbuk gergaji kayu kalba hasil degradasi lignin mempunyai aktivitas sebagai antioksidan sehingga mampu menghambat reaksi oksidasi asam linoleat dengan metode TBA, dengan persentase penghambatan ratarata $13,70 \%$ lebih rendah dibanding BHT.

\section{DAFTAR PUSTAKA}

Deman, J.M., 1997, Kimia Makanan, Edisi Kedua, ITB, Bandung 
Faeda, U., Muhtady, A., dan Mulyono, M.W., 2001, Aktivitas Antioksidan in Vitro Ekstrak Metanol Kulit Kayu Angsana, Prosiding, Seminar Nasional Tumbuhan Obat Indonesia XVII, Puslitbang Kimia Terapan LIPI, Bandung

Halliwell, B and J.M.C. Gutteridge, 2000, Free Radical in Biology and Medicine, Oxford University Press, New York.

Pokorny, J., N. Yanishlieva and M. Gordon, 2001, Antioxidant in Food; Practical Applications, CRC Press, New York.
Rastuti, U dan Purwati, 2010, Degradasi Lignin dari Serbuk Gergaji Kayu Kalba

(Albizia Falcataria) dan Identifikasi Struktur Senyawanya, Prosiding, Seminar Nasional Kimia dan Pendidikan Kimia 2010, Undip, Semarang

Trilaksani, W. 2002. Antioksidan : Jenis, Sumber, Mekanisme Kerja dan Peran terhadap Kesehatan (http://rudyct.tripod.com/sem2_02 3/wini_trilaksani.htm). Diakses 20 Maret 2010.

Widjaya,.2003. Peran Antioksidan terhadap Kesehatan Tubuh. Health Choise, Edisi IV. 